\title{
The Politics of Religion and Taxation: Keeping Church and State Separate
}

\author{
Mary Ann Hofmann \\ Appalachian State University
}

This paper discusses tax laws and federal court decisions relating to the taxation or exemption of religious non-profit organizations. In a democracy characterized by separation of church and state, what role does the federal government play in regulating the activities and financial transactions of churches and other religious non-profit organizations? What are the federal statutory requirements regarding tax exemption for churches, tax deductibility of donations to churches, and political activity by churches, and are these requirements justified? Does this regulation interfere with the free exercise of religion, or does the federal government violate the establishment clause of the First Amendment by providing inappropriate tax benefits to churches and clergy?

Keywords: exempt entities, government regulation of religious organizations, free exercise clause, establishment clause of First Amendment

\section{INTRODUCTION}

In the United States, we pride ourselves on promoting and protecting freedom: freedom of speech, freedom of the press, freedom of religion. The First Amendment in our Bill of Rights prohibits Congress from the making of any law respecting an establishment of religion (the Establishment clause), or impeding the free exercise of religion (the Free Exercise clause). Some interpret this to mean that the government must keep a strict "hands off" policy when it comes to religion - that churches are in essence above the law. But realistically, the first amendment simply provides that the government may neither compel nor prohibit religious belief or exercise. The oft cited "wall of separation" between church and state is not articulated in the Constitution or the Bill of Rights. It is simply a phrase used by Thomas Jefferson in a letter to the Baptist Church in 1802. (Jefferson, T., 1998) Federal courts have referred to that "wall" frequently; however, the U.S. Supreme Court has explained that "It has never been thought either possible or desirable to enforce a regime of total separation." (Lynch v. Donnelly, 1984)

The courts have frequently been challenged to determine where the line should be drawn between the legitimate interests of the state and freedom of religion. As District Judge Teitelbaum points out in a case involving an Amish carpenter,

"The free exercise of one's religion is a fundamental, natural, absolute right, firmly entrenched in the foundation and the history of our legal system. Courts have given the First Amendment a broad interpretation in light of its history and the evils it was designed to prevent. When this right has come into conflict with an equally valued and respected governmental interest, the Court will apply a balancing test to determine which must yield 
to the other. A pattern has emerged from these conflicts which has set guidelines for determining the predominate interest. Courts have determined that while religious beliefs may be inviolate, religious conduct is not; therefore, conduct jeopardizing public safety, peace, or order will fall to Governmental interest." (Lee v. U.S, 1980)

Unfortunately, the ambiguous phrasing of the First Amendment creates difficulties of interpretation, and the Establishment and Free Exercise clauses are somewhat contradictory when one attempts to apply them to issues related to the taxation of religious organizations. In 1988, in a case involving a Texas sales tax exemption for religious books and magazines, Supreme Court Justice Blackmun described this dilemma: "The Free Exercise Clause suggests that a special [sales tax] exemption for religious books is required. The Establishment Clause suggests that a special exemption for religious books is forbidden. This tension between mandated and prohibited religious exemptions is well recognized." (Texas Monthly, Inc. v. Bullock, 1988)

The federal government does not go out of its way to write laws regulating churches or religions. If a church incorporates or forms a legal entity (which it would do under state law) for the purpose of holding property, opening a bank account, employing a minister, etc., then many of the laws governing business entities, property owners, and employers will likely be applicable. In the interest of public safety, for example, churches are required to comply with building and fire codes. Most direct government regulation of churches has to do with taxes; or, more accurately, with the fact that churches are presumed to be taxexempt. The federal government, along with most state and local governments, grants tax exemptions to nonprofit organizations, including churches, as a matter of courtesy. "It has never been thought before that freedom from taxation was a prerequisite attaching to the privileges of the First Amendment. The National Government grants exemptions to ministers and churches because it wishes to do so, not because the Constitution compels." (Murdock v. Commonwealth of Pennsylvania, 1943) In fact, the Supreme Court's justification for tax exemption for churches has been based most often on the historical premise that churches devote significant resources to charitable work and hence should be treated in the same manner as secular charitable organizations. (Hoff, 1991)

Tax exemption for charitable, religious, or educational organizations was part of the original Corporation Excise Tax of 1909. (Scheitle, 2010) The tax deduction for donations to charity was established in 1917, just four years after the federal income tax was introduced. When it comes to obtaining and maintaining tax-exempt status, churches are granted extreme deference (compared to secular nonprofits) by the federal government: churches do not need to apply for or obtain recognition of tax-exempt status, do not need to file an annual return with the IRS, do not need to withhold taxes from compensation paid to ministers, or pay unemployment taxes on employee wages. Furthermore, there are significant limits on the IRS's ability to audit churches. (IRS, 2013) Due to these concessions to churches, the IRS has actually been accused in recent years of religious discrimination against non-religious nonprofits.

Defining the terms is essential, but problematical-what is a religion? And what constitutes a church? And more compellingly, is the federal government in a position to determine those definitions? If any organization calling itself a church gets automatic tax exemption and freedom from most forms of government scrutiny, then it is no wonder that there have been so many tax evasion schemes involving sham churches. Clearly, in order to grant tax exemptions to churches and tax deductions to donors, the government must be able to ensure that an organization calling itself a church is bona fide. IRS Form 1023 is used by a nonprofit applying for tax-exempt status. Schedule A must be completed by any nonprofit calling itself a church. (A copy of Schedule A can be found in the appendix.) The first fourteen questions are based on the characteristics of churches used by the IRS for decades as general guidelines. A church need not possess all of these characteristics, but clearly the answers must provide sufficient evidence that the church is legitimate. The IRS's definition of religion using these characteristics relies heavily on the Seeger test, (United States v. Seeger, 1965), as elaborated upon in Welsh v. United States (1970).

In order to preserve the integrity of the income tax and employment tax systems, the IRS needs to be able to ensure that employees of churches are subject to the same tax withholding and reporting requirements as employees of secular organizations (without placing an undue burden on small churches 
that could be seen as interfering with their right to free exercise). The government also needs to be able to verify that donors taking tax deductions for charitable donations can substantiate the amounts and timing of their donations and provide evidence that the organizations to which they contributed are qualified to receive tax-deductible contributions. It is for these reasons that the federal government must exercise some minimum level of control over organizations claiming to be churches.

This paper discusses the primary areas in which federal tax laws attempt to regulate churches and other nonprofits: authentication and maintenance of tax-exempt status, the tax on unrelated business activities, tax withholding and reporting for employees and self-employed service providers, and substantiation of tax-deductible donations. Finally, the paper provides a summary of some landmark federal court decisions as well as some emerging controversies.

\section{REQUIREMENTS FOR TAX-EXEMPT STATUS UNDER I.R.C. §501(c)(3)}

Internal Revenue Code (I.R.C.) §501(a) provides for tax exemption for organizations described in $\S 501(c)(3)$ as being "organized and operated exclusively for religious, charitable, ... or educational purposes, ... no part of the net earnings of which inures to the benefit of any private shareholder or individual, no substantial part of the activities of which is carrying on propaganda, or otherwise attempting, to influence legislation, ... and which does not participate in, or intervene in (including the publishing or distributing of statements), any political campaign on behalf of (or in opposition to) any candidate for public office."

According to I.R.C. $§ 508$, nonprofit organizations must apply for tax-exempt status by filing IRS Form 1023, a 26-page document that requires information with respect to mission, goals, and organizational structure; financial statements; as well as specific details about past, present and planned activities. Part VI asks questions about members receiving benefits from the organization, and Part VIII asks about political activities. Schedule A, to be completed by churches, asks questions designed to determine that the organization is a bona-fide church. A nonprofit that receives approval as a $\$ 501(\mathrm{c})(3)$ organization is exempt from paying income tax on its net earnings; and there is a presumption that one who contributes to such an organization can deduct the donation from his or her taxable income.

Churches are exempted from filing the IRS Form 1023 in order to obtain tax-exemption. A church may simply hold itself out as a church and claim tax-exempt status pursuant to I.R.C. §508(c). A person contributing to such a church may deduct the contribution from his or her income (under I.R.C. §170(c)), but if audited, has the burden of proving that the church does in fact meet the criteria to qualify as a $\S 501(c)(3)$ organization. A church would fail to meet those criteria if it grants any inurement or private benefit to insiders, if the church engages in substantial lobbying activity, or participates in any political campaign activity.

\section{No Private Benefit or Inurement to Insiders}

The reason for the prohibition against private inurement or private benefit is obvious: the definition of a nonprofit is an organization that does not exist to enrich its owners or investors, but rather that uses its surplus revenues to further its mission. Treasury Regulations regarding IRC §501(c)(3) require that a nonprofit organization must serve a public rather than a private interest. The beneficiaries of the nonprofit's activities must be objects of charity, or the community at large. A nonprofit will not be qualified to receive tax-deductible donations if it exists primarily to serve the private interests of any individual or organization, or if any of its earnings or assets inure to the benefit of insiders. For churches, private inurement could consist of provision of perquisites to leaders or members; payment of unreasonable compensation or inflated rents to founders, ministers, officers, board members, or their families; or transferring property to insiders for less than fair market value. A 1969 case involving the Church of Scientology found that earnings inured to the benefit of the founder in the form of payments to him and to various family members of salaries, rentals, reimbursements, and loans. Judge Collins opined that "The very existence of a private source of loan credit from an organization's earnings may itself amount to inurement of benefit." (Founding Church of Scientology v. U.S., 1969) 
There have been many well-publicized incidents involving television evangelists or mega-church pastors who used donated funds to finance excessively luxurious lifestyles. A search of federal tax cases reveals a host of schemes in which individuals have used some form of "church" for personal tax evasion purposes. In a 1983 case involving a family who made donations to and transferred various sources of income to a church which then paid their living expenses, the Tax Court complained that "...our tolerance for taxpayers who establish churches solely for tax-avoidance purposes is reaching a breaking point." (Miedaner v. Comm., 1983) And yet, many decades later, this type of scam continues to enjoy popularity among tax evaders.

The restriction against private inurement of church income or property has not been challenged on constitutional grounds. It cannot reasonably be considered interference with the free exercise of religion, especially since it applies to all charitable nonprofits, religious or otherwise. As a long list of federal cases has shown, the government has the right to require and to verify that a nonprofit, including a church, serves a religious, educational, or charitable purpose and does not exist primarily for the financial benefit of insiders.

\section{No Lobbying or Political Campaign Activities}

I.R.C. $\$ 501(c)(3)$ nonprofits, including churches, are strictly prohibited from substantial lobbying and from any degree of participation in political campaign activity. The justification for these prohibitions may not be obvious, at least to anyone who is not a tax accountant. Tax law (I.R.C. §162(e)) prohibits any individual or corporation from taking a tax deduction for lobbying expenditures (other than at the local level) or political contributions of any kind. To prevent indirect deductions, the statute further denies any kind of deduction for payment of dues to a trade or professional association to the extent such organization uses its funds to pay for lobbying activities. When Congress prohibits churches and other $\S 501(\mathrm{c})(3)$ organizations from engaging in substantial lobbying or political campaigning, its motive is to preserve the disallowance of a tax deduction for political activities. This restriction prevents taxpayers from converting an otherwise non-deductible political expenditure into a deductible charitable contribution.

That the government is interested primarily in protecting the integrity of the income tax is best illustrated by the case of Branch Ministries, otherwise known as the Church at Pierce Creek. Four days before the 1992 presidential election, Branch Ministries, a tax-exempt church, placed full-page advertisements in The Washington Times and USA Today in which it urged Christians not to vote for thenpresidential candidate Bill Clinton because of his positions on certain social issues. At the bottom of the page was a statement that the advertisement was sponsored by the church and its pastor, and that taxdeductible donations to help pay for such advertisements would be gladly accepted. The ad attracted a fair amount of publicity, and was mentioned in at least two articles in the New York Times, which is likely how it came to the attention of the IRS. (Applebome, 1992; Lewis, 1992) Upon investigation, the IRS concluded that the placement of the advertisements violated the statutory restrictions on organizations exempt from taxation; and in 1995, for the first time in its history it revoked a bona fide church's tax-exempt status because of its involvement in politics. The church challenged the IRS's action on the grounds that the revocation violated its right to the free exercise of religion guaranteed by the First Amendment and equal protection under the Fifth Amendment. Both the U.S. District Court and the U.S. Court of Appeals for the District of Columbia found these objections to be without merit. (Branch Ministries Inc., v. Rossotti, 1999; Branch Ministries v. Comm, 2000)

In the appellate court decision, Senior Circuit Judge Buckley points out that the revocation of Branch Ministries' tax-exempt status

"is more symbolic than substantial. As the IRS confirmed at oral argument, if the Church does not intervene in future political campaigns, it may hold itself out as a 501(c)(3) organization and receive all the benefits of that status. All that will have been lost, in that event, is the advance assurance of deductibility in the event a donor should be audited. Contributions will remain tax deductible as long as donors are able to establish that the Church meets the requirements of section 501(c)(3). Nor does the revocation necessarily 
make the Church liable for the payment of taxes. As the IRS explicitly represented in its brief and reiterated at oral argument, the revocation of the exemption does not convert bona fide donations into income taxable to the Church. Furthermore, we know of no authority, and counsel provided none, to prevent the Church from reapplying for a prospective determination of its tax-exempt status and regaining the advance assurance of deductibility — provided, of course, that it renounces future involvement in political campaigns."

Judge Buckley proceeds to lay out a process by which a church can form a separate $\S 501(\mathrm{c})(4)$ organization that is tax exempt, but does not receive tax-deductible contributions, to conduct lobbying activities; and how that organization can form a Political Action Committee (PAC) to engage in political campaign activities. As long as no tax-deductible donations to the church are used to finance these other organizations, their lobbying activities and political campaign activities will not jeopardize the church's tax-exempt status in any way. It is evident from this discourse by a federal judge that the government's concern is not to bar churches from participating in the political arena, but simply to avoid granting tax deductions to taxpayers who finance political activities.

While the IRS has been vindicated in enforcing the prohibition against political activity by churches, the Branch Ministries case is one of the few, if only, times the IRS has pursued such a course. There are a number of churches and other religious nonprofits that openly engage in lobbying and political campaign activity, yet do not seem to attract the attention of the IRS. In the 1980's, an abortion rights organization unsuccessfully attempted to sue the Catholic Church for engaging in pro-life lobbying and political campaign activity, and the IRS for failing to revoke the tax-exempt status of the Catholic Church. (Abortion Rights Mobilization Inc. v. Regan, 1982; In Re U.S. Catholic Conference et al. v. Abortion Rights Mobilization Inc. et al., 1989) The federal courts appeared hesitant to pursue an inquiry which might expose both the IRS and the Catholic Church to potentially embarrassing public scrutiny. The case was ultimately dismissed due to lack of standing on the part of the plaintiffs - the organization could not show that it had suffered any harm at the hands of the defendants. (Carroll, 1992)

\section{No Criminal Activities}

There are several instances where a church's tax exempt-status was revoked due, at least in part, to criminal activity. In one case, the Zion Coptic Church was shown to be a front for a drug smuggling and distribution operation. (King Shipping Consum, Inc. v. Comm., 1989) As the Special Trial Judge pointed out, "...it is settled law that an exempt organization may not carry on criminal activities and still retain its exemption." In another case, Church of Scientology of California, criminal allegations were made but not proven. (Church of Scientology of California v. Comm, 1984; 823 F.2d 1310, 1987) The court made it clear, however, that "The First Amendment does not shield a church from the constraints of the criminal law, and the Government, through [the IRS], could insist its largesse not subsidize criminal activity. More recently, a case involving a terrorist organization cloaked as a \$501(c)(3) nonprofit, while not a church, did raise First Amendment issues of freedom of religion. (U.S. v. Mubayyid, 2007)

\section{Limitation on IRS Audits of Churches}

I.R.C. $\$ 7611$ prohibits the IRS from auditing a church unless an appropriate high-level Treasury official has reliable, written, third-party evidence that the church is not qualified for tax exemption or is engaged in taxable activity; and even then, the agency must give the church advance notification of the audit and the opportunity to request a pre-examination meeting to attempt to resolve the issue(s) and avoid a full-scale audit. (IRS, 2013) These restrictions significantly hamper the IRS's ability to enforce the I.R.C. In one case, a federal District Court in Minnesota ruled that the IRS's Director of Exempt Organizations Examinations was not an "appropriate high-level Treasury official" and that the IRS therefore could not proceed to audit the church's records for evidence of inappropriate political conduct and transactions resulting in private benefit to the pastor. (U.S. v. Living Word Christian Center, 2008) Over and over, the federal courts have 
held to the position that the IRS's examination of the financial records of a church (when all proper procedures are followed) does not in any way violate its First Amendment rights.

\section{THE UNRELATED BUSINESS INCOME TAX}

Churches and other religious organizations, like secular non-profits, sometimes engage in profitmaking activities that are unrelated to their tax-exempt mission. This does not affect tax-exempt status, as long as such activities are not a substantial part of the organization's overall activities. But the net profit from such activities is subject to the I.R.C. $\$ 511$ Unrelated Business Income Tax (UBIT) if the activity constitutes a regularly-carried-on trade or business. The fact that the income from the business is used to fund the church's tax-exempt activities does not make the activity "related" to its spiritual or charitable mission. So despite its automatic or officially recognized tax-exempt status, a church must file a tax return (IRS Form 990-T) and pay UBIT on its profits if it has more than $\$ 1,000$ of gross income from an unrelated business activity. (IRS, 2013)

For a church, income from gaming (with special exceptions for bingo); income from the sale of advertising in church publications or on church websites; income from the sale of merchandise or services that are not substantially related to its religious mission; income from the rental of debt-financed real estate; or even income from charging the general public for parking in the church parking lot during the workweek, is considered unrelated business income. There are exceptions for business ventures where all labor is performed by volunteers or the business consists of selling merchandise that is donated (e.g., thrift stores). (IRS, 2013)

Congress enacted the UBIT in 1950 because it felt it was necessary to prevent unfair competition. (U.S. Senate, 1950) This legislation was a reaction to the IRS's failed attempt to deny tax exemption to the Mueller macaroni company, which was acquired by New York University School of Law to be operated for its exclusive benefit. (C. F. Mueller Co., 1951). Initially, churches were exempted from UBIT provisions. However, it became apparent that churches were engaging, or were apt to engage, in unrelated business activities. Congress responded in the Tax Reform Act of 1969 by subjecting almost all exempt organizations to the tax on unrelated business income. (IRS, 1999) Several scholars have advanced the theory that, in addition to the prevention of unfair competition, an important aspect of UBIT is the promotion of economic efficiency. (Rose-Ackerman, 1982; Hansman, 1989) If a church owns and operates a coffee shop, for example, and is exempt from income tax on the profit, the church can compete unfairly with other coffee shops in the community that are required to pay income tax. Churches might thus have incentive to operate businesses for which they have no real competitive advantage except that they are exempt from taxation; and that would result in economic inefficiency.

Due to the ability of nonprofits to over-allocate common expenses to their unrelated business activities, UBIT probably does not achieve its objectives in completely leveling the playing field or promoting productive efficiency. (Sansing, 1998) However, it does provide an important gate-keeping function; without it, the doors would be wide open for nonprofits to run all kinds of businesses completely unrelated to their tax-exempt status, and to avoid income tax on the profits. Does UBIT interfere with the free exercise of religion? This charge has not been brought in a federal court. Apparently, it is reasonable enough to expect that if a church chooses to compete in the business world, it should be required to play by the same rules and pay the same taxes as other businesses.

\section{EMPLOYMENT-RELATED TAX ISSUES}

In the employment arena, churches are treated like any other employer (with important exceptions discussed below): churches are required to withhold, report, and remit income taxes and Federal Insurance Contributions Act (FICA, which consists of Social Security and Medicare) taxes for their employees, and to pay the employer's matching share of FICA taxes on employee compensation. Churches with employees must issue IRS Forms W-2 to all employees by January 31 following the close of the calendar year, and IRS Form 1099 to any unincorporated individual or entity to whom the church paid $\$ 600$ or more during a 
calendar year for rents, commissions, fees, compensation, or other income. Churches are, however, exempt from federal (and usually state) unemployment tax. (IRS, 2013)

\section{Exemption From Withholding Income Tax or FICA Tax From Ministers' Pay}

There are special rules regarding tax withholding for ministers: a church is not required to withhold income tax on compensation paid to duly ordained, commissioned, or licensed ministers for performing services in the exercise of their ministry. (Treas. Reg \$31.3401(a)(9)-1) Such compensation is also exempt from FICA tax on both employer and employee. (I.R.C. \$3121(b)(8)) These exceptions are provided simply to reduce the church's burden of record-keeping and tax-paying. However, under I.R.C. $\$ 1402(\mathrm{c})$, ordained ministers are subject to income tax and self-employment tax-essentially both the employee and employer's share of Social Security and Medicare tax - on their net earnings. An employed minister may enter into a voluntary withholding agreement with the employing church for income taxes; but payment of the self-employment tax is strictly the minister's responsibility. So while it appears initially that ministers are getting a tax benefit, it turns out that only the church benefits from reduced record-keeping and taxfiling: the minister still pays all of the same taxes as other taxpayers. The real question here is, how does the government determine who is a "duly ordained, commissioned, or licensed minister"? That question will be even more important when we look at the parsonage allowance.

\section{Exemption From Social Security Taxes for Those Who Conscientiously Object to Pensions or Insurance}

A church that is opposed to Social Security and Medicare on religious grounds and files IRS Form 8274 is not required to withhold such taxes from any employee's pay. Employees working for such a church are required to pay self-employment taxes on their earnings (unless they have applied for and received an exemption). Members of a religious order who have taken a vow of poverty are exempt. Ministers, members of a religious order who have not taken a vow of poverty, and Christian Science practitioners can file for exemption from FICA and/or self-employment tax if they are willing to waive any claim to benefits under Social Security or Medicare; and members of a recognized sect (e.g., Old Order Amish) that has been in existence since 1950 and that is opposed to insurance on religious grounds may be exempt from FICA and/or self-employment tax. Such individuals must be conscientiously opposed to pension plans or life, disability or medical insurance and must be willing to waive all benefits under Social Security and Medicare. (Lee v. U.S., 1980) This provision was made to appease the Amish, who felt that the federal government was forcing them to violate conscience by requiring them to participate in the Social Security and Medicare pension and insurance programs. (Igou, 2010)

\section{Exclusion for the Parsonage Allowance}

In recent years, one particular employment-related tax benefit for pastors has created considerable controversy: the parsonage (housing) allowance. Under long-standing tax law (I.R.C. §119), any employed person can exclude from gross income the value of housing provided by the employer if it is provided on the employer's business premises, for the convenience of the employer, and is a condition of employment; but other than members of the clergy or military, employees cannot exclude cash housing allowances. In a 1998 private letter ruling the IRS ruled that "The housing allowance paid by [a nonprofit] school to the Headmistress is not excludible from the Headmistress's gross income under the provisions of section 119(a)... since the School did not provide the lodging to the Headmistress in-kind.” (IRS, 1998)

But under I.R.C. $\S 107$, the gross income of a "duly ordained minister of the gospel" does not include the fair rental value of a parsonage, including utilities, provided by the employing church; nor amounts paid as a housing allowance that are used by him or her for rent, mortgage payments, utilities, property taxes, and repairs. This provision, which came into existence in 1954, is a ratification by Congress of what federal courts had ruled in cases such as MacColl v. U.S.(1950), Conning v. Busey (1954), and Williamson v. Comm.(1955).

The phrasing of this law has led to confusion as to what is meant by "minister of the gospel." Are only Christian clergy given this particular tax benefit? In a 1966 case the Tax Court ruled that both cantors and 
rabbis are eligible for the housing allowance exclusion, since their roles are similar to that of a pastor in a Christian church. (Abraham A. Salkov, 1966) Furthermore, what does it take to qualify as duly ordained? A case involving a "minister of education" who was "commissioned" in a Baptist Church forced the Tax Court to provide a clearer definition - and they turned to the dictionary! "Since the statutory phrase 'minister of the gospel' stands without legislative or administrative explanation or definition we must give it its ordinary conventional meaning. The term 'minister' is defined in Webster's Dictionary as 'One duly authorized or licensed to conduct Christian worship, preach the gospel, and administer the sacraments, etc.; esp., a pastor; a clergyman'." (Lawrence, 1968)

In what seems like a particularly egregious preference to ministers, I.R.C. $\S 265(a)(6)$ allows them to deduct home mortgage interest and property taxes that are paid for using tax-free housing allowance funds. This amounts to a double tax benefit, and is contrary to the way the tax law treats other civilian taxpayers in similar situations. (Employees who receive tuition reimbursement as a tax-free fringe benefit, for example, cannot deduct the tuition paid for with such funds, nor can employees who receive tax-free child care reimbursements count the expenses paid with those funds as eligible for the child care credit.) The provision of tax preferences to clergy that are not available to employees of other nonprofit or for-profit organizations has been the subject of recent litigation in federal courts, the results of which are discussed later.

\section{SUBSTANTIATION OF CHARITABLE CONTRIBUTIONS}

The last area of church finance that concerns the IRS is the substantiation and proper use of donations. A church is not required to provide receipts for most donations. However, the donor needs written acknowledgment from a church for any single contribution of $\$ 250$ or more before the donor can claim a charitable contribution deduction on his or her federal income tax return. The provision of a timely, written statement that includes all of the information required by the donor will greatly assist him or her in obtaining a tax deduction for the donation, so churches are usually happy to provide such receipts.

A quid pro quo contribution, where a donor receives goods or services (other than intangible spiritual benefits or items of insubstantial value such as a pen or bookmark) in exchange for a donation of more than $\$ 75$, is subject to special documentation requirements. The donor is allowed to deduct as a charitable contribution only the excess of the value of the donation over the value of the goods or services received in exchange; therefore, the church must provide a good faith estimate of the value of any such goods and services provided, and must include a statement explaining the reduction of the deductible contribution.

On a related note, churches need to exercise caution in the receiving of "earmarked" donations. Donors can receive a tax deduction only for contributions to qualified charities, not for donations to individuals. So when someone writes a check to the local church with the stipulation that it is for "groceries for the Jones family," or for the "pastor's birthday gift," technically that is not a charitable contribution. If such a donor is audited, the IRS will likely disallow any deduction for such payments. The IRS needs evidence that the donation is intended to benefit the church and not a specific individual, that the church has ultimate control and discretion over the use of the funds, and that there is no commitment or understanding that the contribution will benefit a designated individual. (IRS, 2013) This requirement goes back to the prohibition against private inurement to insiders, discussed earlier. Considering the fact that the allowance of a tax deduction for donations to churches is a benefit that is not protected by the Constitution, and that could easily be taken away by Congress or the courts, both churches and donors should be very careful not to push the limits of what qualifies for that benefit.

\section{CONSTITUTIONAL CHALLENGES}

As previous discussions have shown, the vague phrasing and oppositional nature of the Establishment and Free Exercise clauses of the First Amendment create difficulties of interpretation and application to specific tax-related situations. In trying to avoid interference with the free exercise of religion, it is possible to create a situation that discriminates on the basis of religion, which can be interpreted as violating the 
establishment clause of the First Amendment or the equal protection clause of the Fifth or Fourteenth Amendments. The Walz case, although dealing with New York City property taxes rather than the federal income tax, is a landmark U.S. Supreme Court case that illustrates some of these constitutional difficulties. In 1969, Mr. Walz, a New York City property owner, claimed that the City Tax Commission's grant of an exemption to church-owned property indirectly required him to make a contribution to religious bodies and thereby violated the Establishment clause of the First Amendment. (Walz v. Tax Commission of the City of New York, 1970)

The U.S. Supreme Court upheld the NYC property tax exemption for churches, and made the following points: 1) the First Amendment tolerates neither governmentally established religion nor governmental interference with religion; 2) the legislative purpose of tax exemptions is not aimed at establishing, sponsoring, or supporting religion, and New York's legislation simply spares the exercise of religion from the burden of property taxation; and 3) the tax exemption creates only a minimal involvement between church and state, far less than taxation of churches would entail, thus tending to complement and reinforce the desired separation insulating each from the other.

Mr. Walz argued, correctly enough, that every dollar of tax that churches are exempted from is a dollar that other taxpayers will have to pay; thus everyone, religious or not, bears the burden of the exemption offered to churches. The Court responded that abstaining from collecting taxes from churches is not "support" in the same sense as making grants to churches; furthermore, if churches are taxed, then churches are being required to support the government, which also violates separation of church and state. A more compelling argument in Walz would have been that when it comes to basic tax exemption (and the allowance of an income tax deduction for donations), churches and their donors receive no benefits exceeding those of other nonprofit organizations. Those who have no appreciation for the arts are indirectly supporting nonprofit arts organizations with tax dollars. Because such tax benefits are offered equally to any organization that meets the requirements of I.R.C. $\$ 501$ (c), one can hardly argue that the governmentfederal, state, or local-is establishing a religion by exempting churches from taxation. As Chief Justice Burger pointed out in Walz, the availability of tax benefits to all churches has actually helped to foster a greater diversity of religions.

Tax preferences given to churches that are not available to other nonprofits are more difficult to justify. The intent of government may be to avoid burdening churches with recordkeeping requirements that might be interpreted as impeding the free exercise of religion, but is perceived by some as favoritism that violates the Establishment clause. In another Supreme Court case at around the same time as the Walz case, Chief Justice Warren Burger ruled that "for a law to be considered constitutional under the Establishment Clause of the First Amendment, the law must have a legitimate secular purpose, must not have the primary effect of either advancing or inhibiting religion, and also must not result in an excessive entanglement of government and religion. (Lemon v. Kurtzman, 1971)

A later Supreme Court case, Texas Monthly, Inc. v. Bullock (1988) further illustrates the difficulties of applying First Amendment principles to church-state issues. From 1984 to1987 a Texas law exempted religious periodicals from the state sales tax. A publisher of non-religious periodicals sued the State of Texas for a refund of state sales taxes remitted. The District Court ruled that an exclusive exemption for religious periodicals had no basis other than the promotion of religion itself, which was prohibited under the Establishment Clause, and ordered the State of Texas to refund the taxes paid plus interest. However, the Third Texas Court of Appeals reversed in a 2-1 decision. The Court of Appeals determined that the tax exemption met the tests required under Lemon v. Kurtzman (1971) and thus did not violate the Establishment Clause. The U.S. Supreme Court, under Chief Justice Brennan, reversed the appellate decision, finding that the sales tax exemption for religious publications violated the First Amendment as made applicable to the states by the Fourteenth Amendment. The reasons for this determination were that the sales tax exemption for religious publications 1) lacked a secular objective, 2) had the effect of advancing religion, since it effectively endorsed religious belief, and 3) appeared to produce state entanglement with religion (the state had to determine what a "religious" publication was) - in other words, the law did NOT meet the Lemon v. Kurtzman (1971) test. Furthermore, the court found that the exemption was not compelled by the Free Exercise clause, because there was no evidence that the payment of a sales 
tax by subscribers to religious periodicals would offend their religious beliefs or inhibit religious exercise. Justice White, in his concurring opinion, pointed out that the sales tax exemption also violated the First Amendment's free press guaranty, since it discriminated on the basis of the content of publications. (Texas Monthly, Inc. v. Bullock, 1988)

Recently, various non-religious groups have initiated litigation against the federal government (specifically the IRS) regarding tax preferences granted solely to churches. The Freedom from Religion Foundation (FFRF) has been unsuccessful in its attempts to sue the IRS for discrimination on administrative issues; namely, that 1) the IRS does not enforce the prohibition on political activity against churches as strictly as it does for non-religious nonprofits (Freedom From Religion Foundation v. Werfel, 2013), and 2 ) the IRS does not impose the same filing requirements on churches that it does on non-religious nonprofits FREEDOM FROM RELIGION FOUNDATION v. WERFEL, 112 AFTR 2d 2013-5951, Code Sec(s) 501; 7421, (DC WI), 08/22/2013. FFRF claims that such disparate treatment violates the foundation's rights under both the Establishment Clause of the First Amendment and the Equal Protection component of the Fifth Amendment.

After a protracted fight, the FFRF recently surrendered on the issue of the parsonage allowance. In November 2013, District Judge Barbara Crabb of the US District Court in Western Wisconsin ruled that I.R.C. $\S 107(2)$, which provides for the exclusion of cash housing allowances paid to clergy, violates the Establishment Clause of the First Amendment “...because the exemption provides a benefit to religious persons and no one else, even though doing so is not necessary to alleviate a special burden on religious exercise." (Freedom from Religion Foundation, Inc. v. Lew, 2013) The case was overturned by the U.S. Court of Appeals for the Seventh Circuit in Chicago in November, 2014, due to FFRF's lack of standing to sue (because no one at FFRF had asked for nor been denied a parsonage allowance). (Freedom from Religion Foundation, Inc. v. Lew, 2014) So in 2017 an employee of FFRF who was denied the equivalent of a parsonage allowance exclusion brought suit in Wisconsin, and Judge Crabb again declared the parsonage allowance to be unconstitutional and issued an injunction barring the federal government from enforcing I.R.C. $\$ 107(2)$. (Gaylor v. Mnuchin, 2017) Of course, the government appealed, and in March, 2019 the Seventh Circuit again overturned the District Court, stating that the parsonage allowance "provision falls into the play between the joints of the Free Exercise Clause and the Establishment Clause: neither commanded by the former, nor proscribed by the latter." (Gaylor, et al. v. Mnuchin, et al., 2019) FFRF decided not to appeal the decision. They had little confidence at that point that the conservative Supreme Court would be sympathetic.

In 2014, American Atheists, Inc. sued in federal District Court in Kentucky to enjoin the government from enforcing I.R.C. provisions that allegedly provide unconstitutional preferential treatment to taxexempt churches. The case was dismissed due to lack of standing. The court did admit, however, that the Atheists present a plausible claim for relief under the Establishment Clause of the First Amendment. (American Atheists, Inc., et al., 2014) One can speculate as to the motives of the American Atheists or the FFRF in pressing these issues, since they are not likely to benefit even if they win, but they do make a valid point that tax laws that show unwarranted favoritism to churches or clergy potentially violate the principle of separation of church and state.

\section{CONCLUSION}

The federal government has long struggled with balancing the protections of the Establishment clause with those of the Free Exercise clause. Federal judges and Supreme Court justices have differed on their interpretation and application of these First Amendment rights and how they should guide the interactions between church and state. Shifting political climates have altered basic assumptions regarding the rights of churches to tax exemption or to special tax benefits not afforded to other nonprofits. Federal courts have developed principles, tests, and doctrines to aid in analyzing laws that affect churches, but even those can be subjective and difficult to apply to specific situations. The Lemon test (Lemon v. Kurtzman, 1971) has been proven to be inadequate for judging the constitutionality of tax laws as they apply to churches and religions organizations. (Zelinsky, 2012) Anti-religious organizations are aggressively challenging 
preferences given to churches, even though they and their members would likely not benefit in any measurable way if those preferences were removed.

It seems obvious that if churches and religious organizations were not treated any differently than other nonprofits, much of the controversy would subside. To take it one step further, if there were no tax exemption for nonprofits, and no tax deduction available for contributions to §501(c)(3) nonprofits, almost all of the controversies discussed in this paper would disappear. The government would have no reason to monitor the political or financial activities of nonprofits beyond the normal auditing of tax returns. The remaining question would be whether the government, by taxing churches, is placing itself above God. Many religious individuals and organizations would find that idea to be highly offensive. And further problems arise: would the non-profit sector survive without tax exemption or without the availability of tax deductions for donors? And what would be the political cost to legislators of introducing such changes to the tax law? There are no easy answers. The issues discussed in this paper are far from resolved, and there remains the potential for broad-reaching changes in the landscape of church-state relations in the future.

\section{REFERENCES}

Abortion Rights Mobilization Inc. v. Regan, 544 F. Supp. 471 (DC NY 1982).

American Atheists, Inc., et al. v. Shulman, 21 F. Supp. 3d 856 (DC KY 2014).

Applebome, P. (1992, October 31). Religious Right Intensifies Campaign for Bush. The New York Times. (October 31, 1992, Saturday, Late Edition - Final).

Branch Ministries v. Commissioner, 211 F3d 137 (CA-Dist. Col. 2000).

Branch Ministries Inc. v. Rossotti, 40 F.Supp.2d 15 (DC Dist. Col. 1999).

Conning v. Busey, 127 F.Supp. 958, (DC OH 1954).

Church of Scientology of California v. Commissioner, 83 TC 381 (1984); 823 F.2d 1310 (CA-9 1987).

Founding Church of Scientology v. U.S., 412 F.2d 1197 (Federal Claims 1969).

Freedom from Religion Foundation, Inc. v. Lew, 773 F.3d 815 (CA-7 2014).

Freedom from Religion Foundation v. Koskinen, 114 AFTR 2d 2014-5610 (DC WI 2014).

Freedom from Religion Foundation, Inc. v. Lew, 983 F. Supp. 2d 1051 (DC WI 2013).

Freedom from Religion Foundation v. Werfel, 112 AFTR 2d 2013-5951 (DC WI 2013).

Gaylor v. Mnuchin, 278 F. Supp. 3d 1081 (DC WI 2017).

Gaylor, et al. v. Mnuchin, et al., 919 F3d 420 (CA-7 2019).

Hansman, H. (1989). Unfair competition and the unrelated business income tax. Virginia Law Review, $75(3), 605-635$.

Hoff, R.P. (1991). The financial accountability of churches for federal income tax purposes:

Establishment or free exercise? Virginia Tax Review, 11(1), 71-136.

Igou, B. (2010). Amish Country News. Retrieved September 4, 2013, from http://www.amishnews.com/amisharticles/amishss.htm.

In Re U.S. Catholic Conference et al. v. Abortion Rights Mobilization Inc. et al., 885 F.2d 1020 (CA-2 1989).

Internal Revenue Service. (2013). Publication 1828: Tax Guide for Churches and Religious

Organizations. Washington, DC: IRS.

Internal Revenue Service. (1999). Internal Revenue Manual 7.27.4.1.2 (02-23-1999).

Internal Revenue Service. (1998). PLR 9801023 (01/02/1998).

Jefferson, T. (1998). Jefferson's Letter to the Danbury Baptists: The Final Letter, as Sent. The Library of Congress Information Bulletin, 57(6).

King Shipping Consum, Inc. v. Commissioner, 58 TCM 574 (1989).

Lawrence v. Commissioner, 50 TC 494 (1968).

Lewis, A. (1992, November 30). Abroad at Home: Tax-Exempt Politics? The New York Times, p. A15.

Lee v. U.S, 497 F. Supp. 180 (DC PA 1980).

Lemon v. Kurtzman, 403 U.S. 602 (1971).

Lynch v. Donnelly, 465 U.S. 668 (1984). 
MacColl v. U.S., 91 F. Supp. 721 (DC IL 1950).

Miedaner v. Commissioner, 81 TC 272 (1983).

Murdock v. Commonwealth of Pennsylvania, 319 U.S. 105 (1943).

Salkov v. Commissioner, 46 T.C. 190, 194 (1966).

Scheitle, C. P. (2010). Beyond the Congregation: Christian Nonprofits in the United States. New York, NY: Oxford University Press.

Texas Monthly, Inc. v. Bullock, 489 U.S. 1 (1988).

United States v. Seeger, 380 U.S. 163 (1965).

U.S. Senate. (1950). Revenue Act of 1950, Report of the Committee on Finance. In Internal Revenue Bulletin 1950-2 CB (pp. 408-410). Washington, DC: Government Printing Office.

U.S. v. Living Word Christian Center, 102 AFTR2d 2008-7220; 103 AFTR 2d 2009-714 (DC MN 2008, 2009).

U.S. v. Mubayyid, 476 F. Supp. 2d 46 (DC MA 2007).

Walz v. Tax Commission of the City of New York, 397 U.S. 664 (1970).

Welsh v. United States, 398 U.S. 333 (1970).

Williamson v. Commissioner, 224 F.2d 377 (CA-8 1955). 


\section{APPENDIX \\ THE IRS FORM 1023, SCHEDULE A}

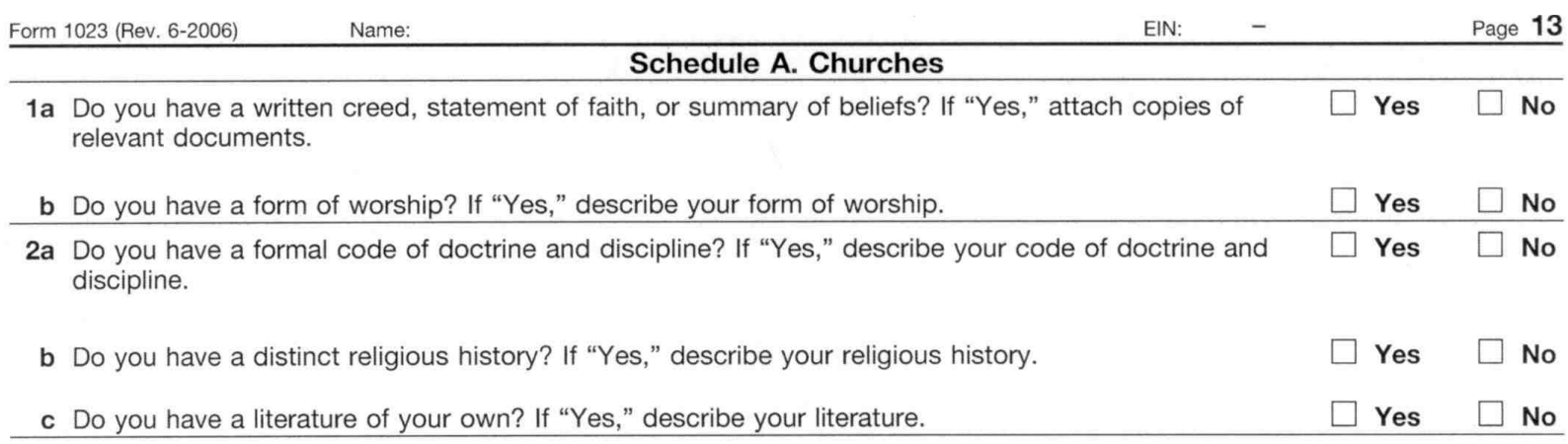

3 Describe the organization's religious hierarchy or ecclesiastical government.

4a Do you have regularly scheduled religious services? If "Yes," describe the nature of the services and $\square$ Yes $\square$ No provide representative copies of relevant literature such as church bulletins.

b What is the average attendance at your regularly scheduled religious services?

5a Do you have an established place of worship? If "Yes," refer to the instructions for the information $\quad \square$ Yes $\square$ No required.

b Do you own the property where you have an established place of worship?

Yes $\square$ No

6 Do you have an established congregation or other regular membership group? If "No," refer to the instructions.

Yes $\square$ No

7 How many members do you have?

8a Do you have a process by which an individual becomes a member? If "Yes," describe the process $\quad \square$ Yes $\square$ No and complete lines $8 \mathrm{~b}-8 \mathrm{~d}$, below.

b If you have members, do your members have voting rights, rights to participate in religious functions, $\square$ Yes $\square$ No or other rights? If "Yes," describe the rights your members have.

c May your members be associated with another denomination or church? $\quad \square$ Yes $\square$ No

d Are all of your members part of the same family?

Yes $\square$ No

9 Do you conduct baptisms, weddings, funerals, etc.? $\quad \square$ Yes $\square$ No

10 Do you have a school for the religious instruction of the young? $\quad \square$ Yes $\square$ No

11a Do you have a minister or religious leader? If "Yes," describe this person's role and explain whether $\square$ Yes $\square$ No the minister or religious leader was ordained, commissioned, or licensed after a prescribed course of study.

b Do you have schools for the preparation of your ordained ministers or religious leaders?

Yes $\square$ No

12 Is your minister or religious leader also one of your officers, directors, or trustees? $\quad \square$ Yes $\square$ No

13 Do you ordain, commission, or license ministers or religious leaders? If "Yes," describe the $\quad \square$ Yes $\square$ No requirements for ordination, commission, or licensure.

14 Are you part of a group of churches with similar beliefs and structures? If "Yes," explain. Include the $\square$ Yes $\square$ No name of the group of churches.

15 Do you issue church charters? If "Yes," describe the requirements for issuing a charter. $\quad \square$ Yes $\square$ No

16 Did you pay a fee for a church charter? If "Yes," attach a copy of the charter. $\quad \square$ Yes $\square$ No

17 Do you have other information you believe should be considered regarding your status as a church? $\square$ Yes $\square$ No If "Yes," explain. 